\title{
A study on maternal and fetal outcome in vacuum extraction
}

\author{
Bhagyashree M Gadwal ${ }^{1 *}$, Uma S Andola² \\ ${ }^{1}$ Assistant Professor, 2Professor, Department of Obstetrics and Gynecology, Basaveshwar Teaching and Hospital, Kalaburagi, INDIA. \\ Email: drbhagyasharan@gmail.com, drskandola@gmail.com
}

Abstract Background: Every year millions of women worldwide require instrumental delivery. The safety and efficiency of vacuum extraction for mother and neonate have been established, its use has gained popularity. The present study is to analyze the maternal and neonatal outcome in vacuum extraction. Objectives: To study maternal and neonatal outcome in vacuum extraction Methods: A descriptive study was conducted in Basaveshwar teaching and general hospital and Sangameshwar hospital Gulbarga, both attached to Mahadevappa Rampure Medical College Gulbarga. Data was analysed using SPSS software and results were presented as proportions. Chi test was used to know the differences among proportions. Results: Majority of the women were in the age group of 20-25 years (70\%) and primiparae were the most common which consisted $55 \%$ of the study population. Fetal distress $(31 \%)$ was the most common indication for vacuum extraction followed by previous caesarean section $(20 \%) .66 \%$ of vacuum extraction completed within 10 minutes. $16 \%$ of the mothers had complications out of which $4 \%$ were post-partum haemorrhage. No neonatal mortality was recorded in the present study. Conclusions: Vacuum extraction method of delivery is an efficient method of assisted delivery with low failure rates. It also offers a method of delivery with low maternal and fetal complications.

Key words: Vacuum extraction, assisted delivery, maternal outcome

*Address for Correspondence:

Dr Bhagyashree M.Gadwal H.No L-86713/2 Behind Govt ITI College Venkatesh Nagar Kalaburagi- 585102 2. INDIA.

Email: drbhagyasharan@gmail.com, drskandola@gmail.com

Received Date: 12/04/2020 Revised Date: 23/06/2020 Accepted Date: 14/07/2020

DOI: https://doi.org/10.26611/10121533

This work is licensed under a Creative Commons Attribution-NonCommercial 4.0 International License. $($ (c) ) EY-NC

\begin{tabular}{|l|l|}
\hline \multicolumn{2}{|c|}{ Access this article online } \\
\hline Quick Response Code: & Website: \\
& www.medpulse.in \\
& \\
\hline
\end{tabular}

\section{INTRODUCTION}

Every year millions of women worldwide require instrumental delivery. In the vast majority of instrumental deliveries, the choice of instrument largely rests on the preference of the attending obstetrician. The safety and efficiency of vacuum extraction for mother and neonate have been established, its use has gained popularity. The relative merits of the vacuum extractor have been extensively studied and its advantages are analyzed. These include its ease of application, encouragement of 'autorotation' of the malpositioned fetal head, its safety for both fetus and especially mother. Therefore a wider acceptance and usage of vacuum extractor might result in better outcome in millions of instrumental deliveries performed each year. The purpose of the present study is to analyze the maternal and neonatal outcome in vacuum extraction.

\section{MATERIALS AND METHODS}

A descriptive study was conducted in Basaveshwar teaching and general hospital and Sangameshwar hospital Gulbarga, both attached to Mahadevappa Rampure Medical College Gulbarga of North Karnataka. Study was conducted from December 2008 to June 2010. Ethical Clearance was obtained from Institutional ethical committee of M R Medical College. All women who got admitted for and taken for vacuum extraction were included in the study. Chi-square test was used for analysis.

Inclusion criteria:

Term and post term pregnancies, Any parity, Cephalic presentation, Cervical dilatation $8 \mathrm{~cm}$ and above, Malposition or short of rotation, Prolonged II stage of labor, Poor maternal efforts, to cut short II stage of labormedical disorders associated with pregnancy, previous LSCS, Non reassuring fetal status.

Exclusion criteria:

Fetal distress, Cephalo pelvic disproportion, Intra uterine death. 
There were a total of 100 women who got admitted with the above inclusion and exclusion criteria. Complete history was taken, general examination, systemic examination along with obstetric examination was done. Baseline blood and urine investigations, admission test and USG abdomen were done. The vacuum cups used in present study were flexible, silastic cups of two sizes with $40 \mathrm{~mm}$ and $60 \mathrm{~mm}$ diameter and the suction apparatus with suction force from $0-760 \mathrm{mmHg}$ ( or 50-60 $\mathrm{cm}$ of $\mathrm{Hg}$ or 60$80 \mathrm{kPa}$ ). The selected parturient was placed in dorsal position, parts scrubbed, bladder emptied and thorough pelvic examination was done to confirm all findings. The cup was lubricated with antiseptic solution, then partially collapsed cup introduced into vagina after gently spreading the labia and positioned against fetal head on the flexion point. Then the suction apparatus was started and pressure raised between $450-600 \mathrm{mmHg}$ and waited for $2-5 \mathrm{~min}$ till the chignon was formed. The traction was given with each uterine contractions and maternal efforts. If delivery was not achieved within 3-4 applications or within 30mins, then the procedure was discontinued and women were posted for LSCS. After delivery maternal and fetal complications were studied. Neonatal scalp was examined for injuries after resuscitation and in post natal visits. Maternal birth canal injuries examined along with blood loss. Babies with serum bilirubin more than $8 \mathrm{mg} / \mathrm{dl}$ were taken as significant neonatal jaundice. In the present study all 100 women delivered by vacuum extraction within 3 attempts and within $30 \mathrm{~min}$.

\section{RESULTS}

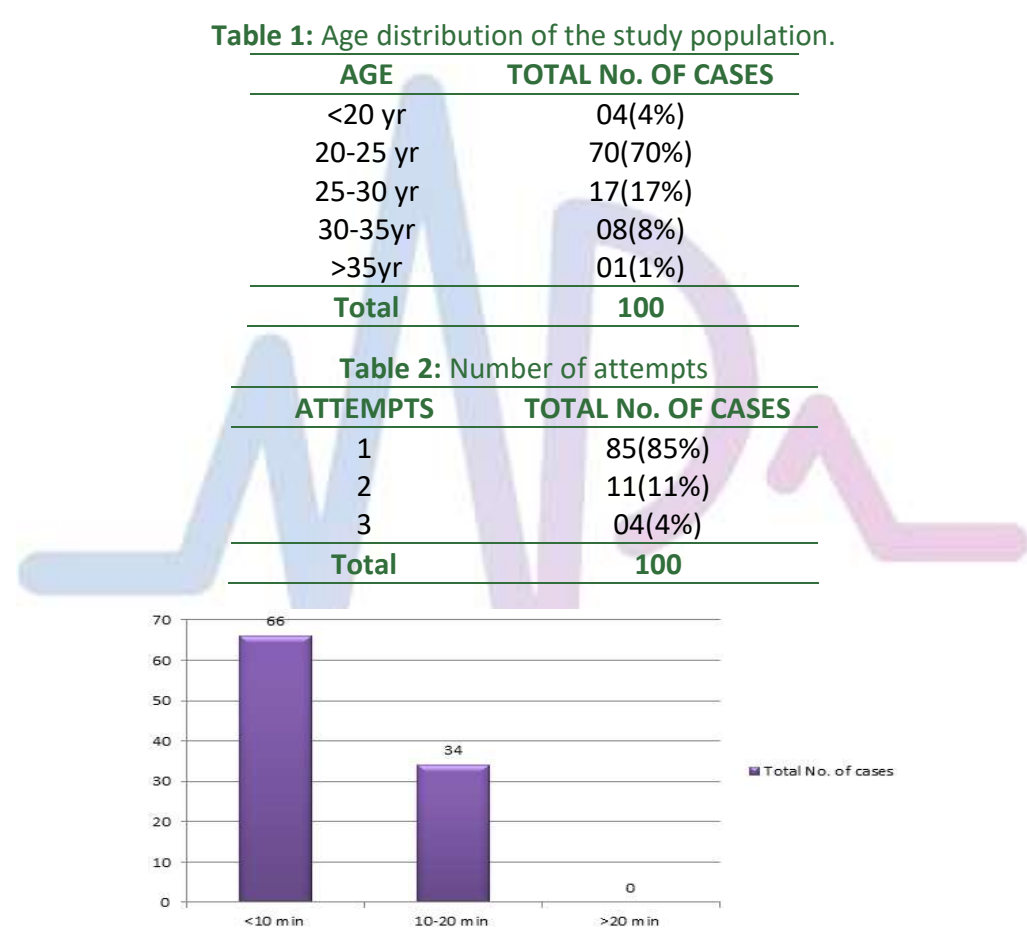

Figure 1: Application of vacuum extraction to delivery interval

\begin{tabular}{|c|c|c|c|c|c|}
\hline \multirow[t]{2}{*}{ Maternal Complication } & \multirow[t]{2}{*}{$\mathbf{N}$} & \multicolumn{2}{|c|}{$\begin{array}{l}\text { Appl. Delivery } \\
\text { Interval }\end{array}$} & \multirow[t]{2}{*}{ F-test statistic } & \multirow[t]{2}{*}{ p-value } \\
\hline & & Mean & Std. Dev. & & \\
\hline With & 26 & 10.0min & $2.4 \mathrm{~min}$ & & \\
\hline Without & 74 & 10.0min & $2.6 \mathrm{~min}$ & 1.32 & $p>0.05$ \\
\hline
\end{tabular}

Table 4: Comparison of application delivery interval in major and minor maternal complication

\begin{tabular}{cccccc}
\hline Maternal Complication & $\mathrm{N}$ & \multicolumn{2}{c}{ Appl. Delivery Interval } & F-test statistic & $\mathrm{p}$-value \\
\cline { 3 - 4 } & & Mean & Std. Dev. & & \\
\hline Major & 04 & $11.0 \mathrm{~min}$ & $2.2 \mathrm{~min}$ & & \\
Minor & 22 & $10.0 \mathrm{~min}$ & $2.7 \mathrm{~min}$ & 1.41 & $\mathrm{p}>0.05$ \\
\hline
\end{tabular}


Table 5: Application delivery intervals and neonatal complication

\begin{tabular}{cccccc}
\hline Fetal Complication & $\mathbf{N}$ & \multicolumn{2}{c}{$\begin{array}{c}\text { Appl. Delivery } \\
\text { Interval }\end{array}$} & F-test statistic & p-value \\
\cline { 2 - 5 } & & Mean & Std. Dev. & \\
\hline With & 19 & $11.0 \mathrm{~min}$ & $2.9 \mathrm{~min}$ & & \\
Without & 81 & $10.0 \mathrm{~min}$ & $2.4 \mathrm{~min}$ & 1.47 & $\mathrm{p}>0.05$ \\
\hline
\end{tabular}

\section{DISCUSSION}

Silastic cup vacuum extraction method of delivery has been an increasing trend in instrumental deliveries. Although not a replacement for all forceps manoeuvers, it has been found to be an efficient method of assisted delivery with a low failure rates. In well selected cases head rotation can be effected, thus avoiding a difficult forceps delivery. In the present study there wre 100 cases of vacuum extractions at Basavshwar teaching and general hospital and Sangameshwar hospital attached to Mahadevappa Rampure Medical College Gulbarga. The average age of study population was 23 years (Table 1) and most of the women belonged to the 20-25 year age group. $55 \%$ of the study population were primiparae and this proportion was similar to the many other studies like the conducted by Thomas F et al. ${ }^{(1)}(70 \%)$ and Shahla Baloach et $a l .^{(2)}(45 \%)$. Present study showed $66 \%$ of the vacuum extractions were completed within 10 minutes and the results were very much similar to Thompason F et al.1 study where $90 \%$ were completed within 10 minutes. (Figure 1) Episiotomy was performed in $66 \%$ of cases as per Bofill $\mathrm{J}$ et $a l^{(3}$ and in present study episiotomy was performed in $88 \%$ of the cases. Mean fetal weight according to J Low et al. was $3.2 \mathrm{~kg}$ and according to $\mathrm{N}$ prapas et al. et al. ${ }^{4}$ was $3.3 \mathrm{~kg}$ and our present study has shown $2.8 \mathrm{~kg}$. J low et al..$^{5}$ study has shown $90 \%$ of the babies with apgar score more than 7 at 5 minutes, our present study has shown $83 \%$.

Maternal complications:

Rizwana Chowdhary et $a .^{6}$ has shown $16 \%$ of maternal complication with 4\% PPH, present study has shown $24 \%$ with $2 \% \mathrm{PPH}($ atonic $\mathrm{PPH})$. Other complications like III $^{\circ}$ perineal tear was $2.5 \%$ and $3.5 \%$ as per Shahla Baloach et al. and $\mathrm{N}$ prapas et al. respectively and in present study it was $1 \%$. Mucosal extention of episiotomy was seen in $8 \%$ of the cases in present study where as $17.2 \%$ cases in Shahla Baloach et al. Para urethral tears were there in 3\% of cases and $0.3 \%$ cases in $\mathrm{N}$ prapas et al. $\mathrm{I}^{\circ}$ perinael tears were $3 \%$ in present study and $13.6 \%$ in $\mathrm{N}$ prapas et al. IV ${ }^{\circ}$ perineal tear was $1.6 \%$ in Shahla Baloach et al. where as in present study it was $0 \%$.

\section{NICU ADMISSIONS}

$\mathrm{N}$ prapas et al. has shown 11\% NICU admissions and present study has shown 19\% NICU admissions. As per Rizwana Chowdhari et al. $6 \%$ of the babies had birth asphyxia and $10 \%$ in present study. No neonatal mortality was recorded in present study. Present study showed no statistically significant difference between the application and delivery interval with maternal and neonatal complications.

\section{CONCLUSIONS}

Although not a replacement for all forceps manoeuvers, silastic vacuum extraction has been found to be an efficient method of assisted delivery with a low failure rates. In well selected cases head rotation can be effected, thus avoiding a difficult forceps delivery.

In our study it was found that, in a well selected case of vacuum extraction there was low incidence of maternal trauma and blood loss. Even neonatal injuries were less, neonatal jaundice was common, but the majority did not require phototherapy. Major fetal trauma could be avoided by proper judgement of difficult vacuum extraction. We can therefore conclude that the silastic cup vacuum extraction offers a safe and efficient method of delivery under the appropriate clinical circumstances.

\section{REFERENCES}

1. Thomas F. Baskett, MB, Cora A. Fanning, RN, David C. Young, MD. A Prospective Observational Study of 1000 Vacuum Assisted Deliveries With the OmniCup Device. JOGC JUILLET, 2008; 573 .

2. Shahla Baloach, Mehrunnisa Khasskheli, Imdada kousik, Aneela Sheeba. J Ayub Med Col Abbottabad 2008; 20:1.

3. Bofill $\mathrm{J}$ etal. A randomised prospective trial of the obstetric forceps versusthe M-cupvacuum extractor. Am. J Obstet Gynecol, Nov. 1996

4. N Prapas et al.. Operative vaginal delivery in singleton pregnancies: short term maternal and neonatal outcomes. Hippokratia Med J.2009; 13 (1): 43-45.

5. J Low, T Y Ng, S Y Chew. Clinical experience with the Silc Cup Vacuum Extractor.singapur Med J. 34:135-138.

6. Rizwana Chowdary, Shazia Syed. Ventouse Delivery: Maternal and Fetal outcome. J Rawal Med Col. Dec 2002; 6(2):60-64.

\section{Source of Support: None Declared} Conflict of Interest: None Declared

\section{Policy for Articles with Open Access:}

Authors who publish with MedPulse International Journal of Gynaecology, (Print ISSN: 2579-0870) (Online ISSN: 2636-4719) agree to the following terms: Authors retain copyright and grant the journal right of first publication with the work simultaneously licensed under a Creative Commons Attribution License that allows others to share the work with an acknowledgement of the work's authorship and initial publication in this journal.

Authors are permitted and encouraged to post links to their work online (e.g., in institutional repositories or on their website) prior to and during the submission process, as it can lead to productive exchanges, as well as earlier and greater citation of published work. 